\title{
Die mooiste meisie van Genua: Die moderne mens in 'n globaliserende wêreld
}

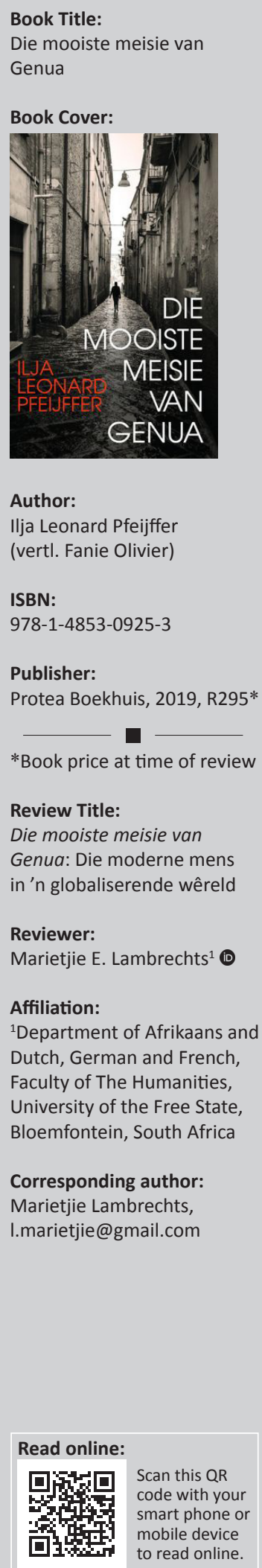

Die mooiste meisie van Genua, wenner van die 2014 Libris Literatuurprys in Nederland, vorm deel van ' $n$ al hoe groter wordende korpus migranteliteratuur wêreldwyd. Tog verskil die roman in belangrike opsigte van ander literêre werke wat reeds in hierdie genre gepubliseer is. Migranteliteratuurtekste met eiesoortige temas fokus op die persoonlike ervarings van migrante, maar in hierdie roman gooi die outeur sy net veel wyer. Twee heterogene ervaringswêrelde, naamlik dié van migrante en dié van die inheemse bevolking in 'n gasheerland, word deur middel van fantasie, illusies en geweld saamgevoeg om as agtergrond te dien waarteen die menslike kondisie in toenemend gefragmenteerde samelewings ondersoek word.

Die roman vertel die verhaal van die migrasie van Ilja, skrywer van beroep, uit Nederland na Genua. As vrywillige banneling wil hy enersyds ontsnap van 'n selfgenoegsame en vervelige lewenswyse wat sy kreatiwiteit inhibeer, en andersyds om inspirasie vir 'n nuwe roman te vind. Hy beskou die Italiaanse hawestad as sy nuwe permanente tuiste en laat geen steen onaangeroer om met die inheemse bevolking te assimileer nie. Daar aangekom, vind hy dat hierdie proses aansienlik moeiliker is as wat hy voorsien het. Daagliks sit hy in die 'Kroeg van Spieëls' en maak homself wys dat hy naatloos by die inheemse bevolking inskakel, maar niks is verder van die waarheid nie. Mettertyd begin Ilja om die persoonlike ervarings van migrante uit verskillende agtergronde en wêrelddele noukeurig in sy joernaal op te teken, met die voorneme om hierdie verhale in 'n migranteliteratuurroman te verwerk. Al beskou Ilja homself vanweë sy Europese agtergrond nie tegnies as 'n migrant nie, bly hy vir die inheemse bevolking ' $n$ buitestander en word hy as sodanig behandel. Gekonfronteer met dieselfde aanpassingsprobleme as migrante uit Afrika, verander sy rol van selfgenoegsame waarnemer wat ander se verhale opteken, na 'n volwaardige deelnemer of karakter wat op persoonlike - sowel as op emosionele - vlak intens by die verhaalgebeure ingesuig word. In wisselwerking met'n verskeidenheid karakters word Ilja bewus van elke mens se primordiale behoefte aan oorlewing. Dit is die groot gelykmaker tussen alle mense, ongeag afkoms of agtergrond.

Ten einde' $n$ beeld van sukses, selfgenoegsaamheid en menswaardigheid voor te hou, is indiwidue bereid om goed en bloed op te offer in 'n poging om 'n eie hopelose toestand en 'n gebrek aan lewensmiddele vir ander lede van die gemeenskap te verberg. Hierdie realiteit lei daartoe dat indiwidue 'n geïdealiseerde beeld van hulself voorstel en dit onder alle omstandighede kunsmatig in stand probeer hou. Realiteite word algaande al hoe makliker omvorm en aangepas om te korreleer met die algemeen aanvaarde norme van volmaaktheid en 'n geïdealiseerde werklikheid. Indiwidue wat nie kan slaag om hierdie fantasie in stand te hou nie, vervreem mettertyd van hulself en begin koersloos in 'n vervreemdende wêreld ronddobber, waar niks en niemand vertrou kan word nie - ook nie hulself of hul eie oordeel nie. Die inheemse bevolking van die stad steek ' $n$ vereensaamde en angsbevange indiwidu agter die masker van ' $n$ aanvaarde beeld weg. Nie net migrante jaag 'n sprokie na nie. Selfs Ilja se beeld van die mooiste meisie in Genua ontsnap nie aan hierdie werklikheid nie.

Die fisieke omgewing dra ook die tekens van hierdie skynbestaan. Agter 'n roemryke geskiedenis, skitterende torings en wit marmergeboue verberg Genua ' $n$ ander werklikheid wat agteruitgang, verrotting en verval uitspel. Migrante en ander inwoners verdwaal in die stadskern se stegies, kroeë en hole, 'n labirint sonder enige ontsnappingsroetes. In aansluiting by die motto voor in die roman, verorber die stad sy inwoners meedoënloos en spoeg die reste ná misbruik en uitbuiting in sy agterbuurtes of op sy vullishope uit. Die illusie van Genua as die ideale 'Nuwe Wêreld', is dus niks anders as 'n fantasie van die verbeelding nie.

Deur middel van ironie, woordspelings, paradokse, metafore en vergelykings, ontvou die verhaal van 'n moderne mens wat in kosmopolitiese omstandighede allereers liggaamlik probeer oorleef. Die roman

How to cite this book review: Lambrechts, M.E., 2020, 'Die mooiste meisie van Genua: Die moderne mens in 'n globaliserende wêreld', Literator 41(1), a1683. https://doi.org/10.4102/lit.v41i1.1683

Copyright: () 2020. The Authors. Licensee: AOSIS. This work is licensed under the Creative Commons Attribution License. 
is intens persoonlik, eerlik en reguit; dis ' $n$ brutale weergawe van 'n ontnugterde indiwidu se volledige ervaringswêreld in 'n gefragmenteerde samelewing wat sy morele kompas verloor het. In die afwesigheid van basiese oorlewingsmeganismes, verloën indiwidue hulself deur die verlies van 'n persoonlike identiteit, menswaardigheid en selfrespek. Primordiale dierlike behoeftes rangeer na die voorgrond van die menslike bestaan, en dit het katastrofale gevolge.

Die mooiste meisie van Genua bied 'n nuwe perspektief op die bestaanskrisis van die moderne mens in ' $n$ toenemend globaliserende wêreld. Dit is in meer as een opsig ontstellend en bedoel vir die leser wat bereid is om hom- of haarself bloot te stel aan die eise, maar ook die belonings van 'n konfronterende teks.

Die waarde van vertalings uit Nederlands in Afrikaans kan nooit oorskat word nie, veral as dit so keurig aangebied word as wat Fanie Olivier hier doen. Nie alleen word bande tussen die twee tale gesmee, behou en versterk nie, maar nuwe, andersins geslote ervaringswêrelde word aan die SuidAfrikaanse leserspubliek bekend gestel. 